\title{
Tailings decommissioning options at Mount Nansen, Yukon, Canada ${ }^{\circledR}$
}

\author{
Y.T.J. Kwong CANMET Mining and Mineral Sciences Laboratories, Natural Resources Canada, Canada
}

\begin{abstract}
A total of 250,000 t of tailings enriched in arsenic and cyanide impounded behind an earth dam of suspect physical integrity constitute the greatest environmental liability at an abandoned gold mine on Mount Nansen, Yukon Territory, Canada. The primary cause of dam deterioration can be traced back to improper initial tailings placement, resulting in gradual melting of frozen ground into which the dam was keyed. Field investigation and sampling revealed that permafrost still underlay most of the impoundment. Subsequent comprehensive mineralogical and geochemical characterisation of the collected samples indicated that the tailings remained relatively stable chemically with low potential for metal leaching. Given that cyanide and related compounds continued to degrade naturally, rendering the tailings increasingly benign with time, and that the containment dam is unlikely to collapse catastrophically except perhaps under extreme seismic stress, it is suggested that the impounded tailings need not be relocated for permanent site decommissioning. A viable long-term alternative could involve downstream reinforcement of the dam structure, dewatering the existing shallow pond and covering the tailings with a layer of benign waste rock to arrest erosion and prevent direct access by roaming animals.
\end{abstract}

\section{Introduction}

The abandoned Mount Nansen Mine is located about $60 \mathrm{~km}$ west of the village of Carmacks and $180 \mathrm{~km}$ north of Whitehorse, the capital of Yukon Territory, Canada. The mine exploited a partially oxidised epithermal gold deposit between November 1996 and July 1999, leaving behind 250,000 t of tailings enriched in arsenic and cyanide in an impoundment with an unstable containment dam. The site is identified as one of the 37 priority federal contaminated sites in the three Canadian territories that require remediation to safeguard human and environmental health (Government of Canada, 2005). As final decommissioning plans are being developed, this paper explores viable options based on previous investigations at the site. Following a brief description of the site settings and the tailings impoundment, the results of a detailed assessment of the chemical stability of the impounded tailings are summarised. Integrating field observations, laboratory analyses and other available information on the site, possible alternatives for decommissioning the impounded tailings are then examined. To conclude the paper, the most practical strategy is discussed.

\section{Site settings}

The Mount Nansen Mine lies in the Dawson Range composed of rounded ridges and shallow valleys with elevations ranging from 945 to $1,525 \mathrm{~m}$. The average monthly temperature peaks in July at about $15^{\circ} \mathrm{C}$ and plunges to approximately $-15^{\circ} \mathrm{C}$ in January. The average annual precipitation, occurring mainly as rain in the summer months, is about $25 \mathrm{~cm}$. The winter snow pack is typically 30 to $40 \mathrm{~cm}$. Discontinuous permafrost ranging from 30 to $60 \mathrm{~m}$ thick occurs at a depth varying from 0.4 to $5 \mathrm{~m}$ depending on the ground cover. The active layer is up to $1.5 \mathrm{~m}$ thick.

The regional geology of the Mount Nansen area has been detailed by Carlson (1987) and the local geology and mineralogy discussed by Hart and Langdon (1997). While in operation, the Mount Nansen Mine mainly exploited the Brown-McDade deposit which consists of two types of epithermal mineralisation. These are: (1) gold-silver veins forming a complex swarm hosted in a massive feldspar porphyry dike; and, (2) a siliceous, sulphide-rich breccia mineralised with gold and silver in a pipe-like structure. The two mineralisation types are separated by a complex, steeply dipping fault that crosscuts the Brown-McDade open pit. The Mount Nansen property has not been affected by recent glacial activities and weathering can reach depths in excess of $70 \mathrm{~m}$ from the surface. Where surface and subsurface weathering is intense, bedrock can become friable and unstable. According to Conor Pacific Environmental Technologies Inc. 
(2000), near-surface oxide gold enrichment is well developed in the Brown-McDade mineralisation. Within the oxide zone, gold has been liberated by the oxidation of sulphide minerals and cataclasis. In the subjacent zone, gold and silver bearing sulphides include pyrite, arsenopyrite, sphalerite, galena, bornite, stibnite and chalcopyrite.

\section{The tailings impoundment}

Figure 1 shows the layout of the Mount Nansen Mine. The tailings impoundment, measured about $290 \mathrm{~m}$ by $210 \mathrm{~m}$, is located approximately $1 \mathrm{~km}$ down-gradient and southeast of the Brown-McDade open pit. It lies in the Dome Creek drainage system and is bound to the east by an earth dam and the other sides by diversion ditches redirecting the surface flow downstream. The dam, keyed into the underlying permafrost, consists of a geosynthetic clay liner installed with a compacted sand embankment. The original dam design required the construction of a $50 \mathrm{~m}$ tailings beach along the upstream face of the dam at the start of operations to provide the primary seepage barrier (Klohn Crippen Consultants Ltd, 1995). The designed beach was not installed until late into operation, after elevated pond water levels had occurred. This led to high seepage rates (by as much as an order of magnitude higher than that anticipated in the design), gradually thawing the frozen foundation permafrost soils. In response to physical stability concerns, the operator constructed a toe berm in 1997.

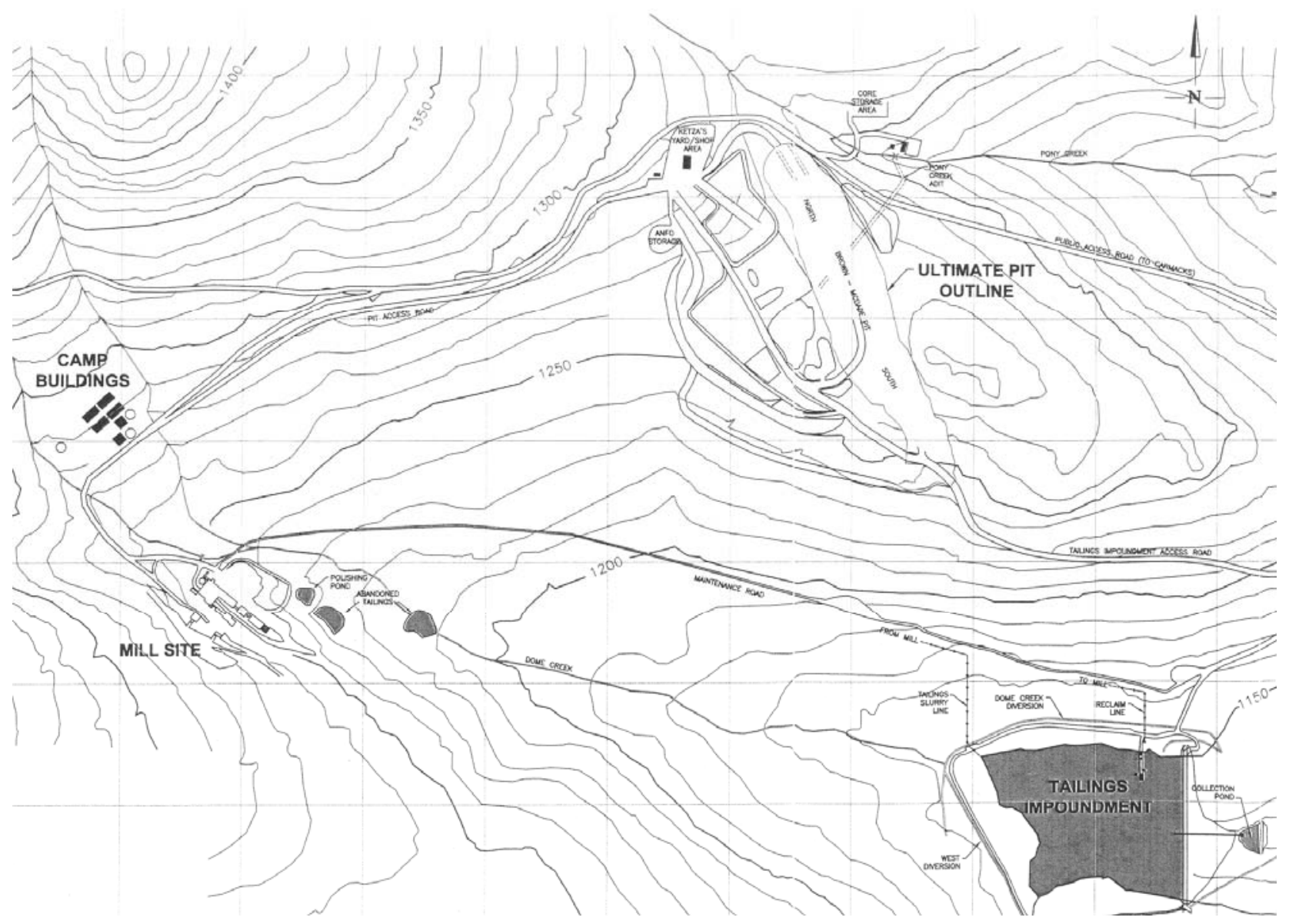

Figure 1 Layout of the Mount Nansen Mine showing the location of the tailings impoundment relative to the open pit and local drainage systems

During mining and since mine abandonment in 1999, seepage has been collected in the collection pond down-gradient of the impoundment and pumped back to the tailings impoundment throughout the year. The pond water is treated on an as-needed basis prior to discharge to the receiving environment. A geotechnical assessment conducted in early 2000 indicated that, despite the high seepage rate, the dam still had a satisfactory factor of safety against slope failure (Klohn Crippen Consultants Ltd, 2000). Another slightly earlier investigation indicated that the native organic soil underlying the dam had thawed in some locations 
but the native sand underlying the organic soil remained frozen (EBA Engineering Consultants Ltd, 1999). Thus, a sudden, catastrophic failure of the dam structure appears to be remote except perhaps during an extreme seismic event.

\section{$4 \quad$ Chemical stability of the impounded tailings}

When the Mount Nansen Mine was in operation, gold was extracted from the arsenic-bearing ore by cyanidation. The occurrence of remnant sulphides in the ore required more cyanide for mineral processing than expected and gave rise to the formation of significant amounts of thiocyanate in the tailings. Approximately 250,000 tonnes of tailings were produced during the short mine life of less than three years. Their chemical stability was a key concern upon mine abandonment. To aid with making decisions in developing a proper reclamation plan for the site, CANMET Mining and Mineral Sciences Laboratories undertook comprehensive field and laboratory studies in 2001 to 2003 to assess the short and long-term chemical stability of the impounded tailings. Some of the key findings have been presented elsewhere (Kwong et al., 2003). Augmented by additional unpublished data, information pertinent to the geochemical behaviour of the impounded tailings is summarised below to facilitate a discussion of viable alternatives for long-term management of the impounded tailings.

\subsection{Field observations and monitoring data}

To systematically sample the impounded tailings for chemical and mineralogical analyses as well as leach testing, 19 holes varying from 2.4 to $9.7 \mathrm{~m}$ deep were drilled in late November 2001 using a sonic drill. Based on their apparent contrasts in mineralogy, colour and texture observed during core logging in the field, the tailings are classified into four categories, namely oxide silt, sulphidic silt, oxide clay and sulphidic clay. The oxide silts and clays range from yellow-brown to light greyish brown in colour while the sulphidic ones are typically greyish brown. From summing core lengths of similar materials, the impounded tailings are estimated to contain $35.0 \%$ oxide silt, $29.8 \%$ oxide clay, $16.5 \%$ sulphidic silt and $18.7 \%$ sulphidic clay. During mining operation, placement of tailings into the impoundment progressed from the east end against the dam to the west end. Predominantly oxidised ore was mined in the beginning but more and more sulphidic materials were excavated during the later stages of mining. This has resulted in the concentration of sulphidic tailings at the west end of the impoundment (Figure 2).

Figure 2 shows two cross sections of the impounded tailings (one in a north-south direction parallel to and about $50 \mathrm{~m}$ from the containment dam and the other in a west-east direction across the middle of the impoundment) illustrating the spatial distribution of the various types of tailings, pond water and the permafrost table. Unfrozen ground was encountered only in the southeast corner of the impoundment adjacent to the containment dam. Seepage is likely most intense in this area.

Both prior to and after mine abandonment, the quality of the tailings pond water and collected seepage has been monitored by the responsible agencies. The temporal variation of six parameters of concern, namely, total cyanide $(\mathrm{CN})$, thiocyanate $(\mathrm{CNS})$, total ammonia $\left(\mathrm{NH}_{3}\right)$, total arsenic $(\mathrm{As})$, total copper $(\mathrm{Cu})$ and total iron (Fe), between April 1997 and August 2001 are depicted in Figures 3 and 4. Salient observations are described below:

- Since the cessation of mining at Mount Nansen, the total $\mathrm{CN}$ and total $\mathrm{Cu}$ levels in both the tailings pond water and seepage continued to decrease with time but there appeared to be insignificant attenuation for thiocyanate and ammonia as of August 2001.

- Total As levels in the pond water were relatively elevated in the early stages of mining operation but little As appeared to have been transported out of the impoundment by seepage either during mining or post-abandonment. The attenuation in aqueous transport of As is probably due to strong sorption with the tailings solids.

- Total Fe levels in the seepage return water were always higher than those in the pond water, suggesting reducing conditions associated with the groundwater flow.

It should be noted that elevated levels of $\mathrm{CNS}, \mathrm{Cu}$ and $\mathrm{NH}_{3}$ in the tailings pond water have been implicated as possible causes of the frequent failure of the untreated water to pass mandatory toxicity tests during mining and afterwards (AGRA Simons Ltd, 2000). As a product of natural degradation of cyanide and 
related compounds accumulated in the impoundment, the $\mathrm{NH}_{3}$ level has remained elevated in the pond water and seepage even after mine abandonment (Figure 3, bottom plot).

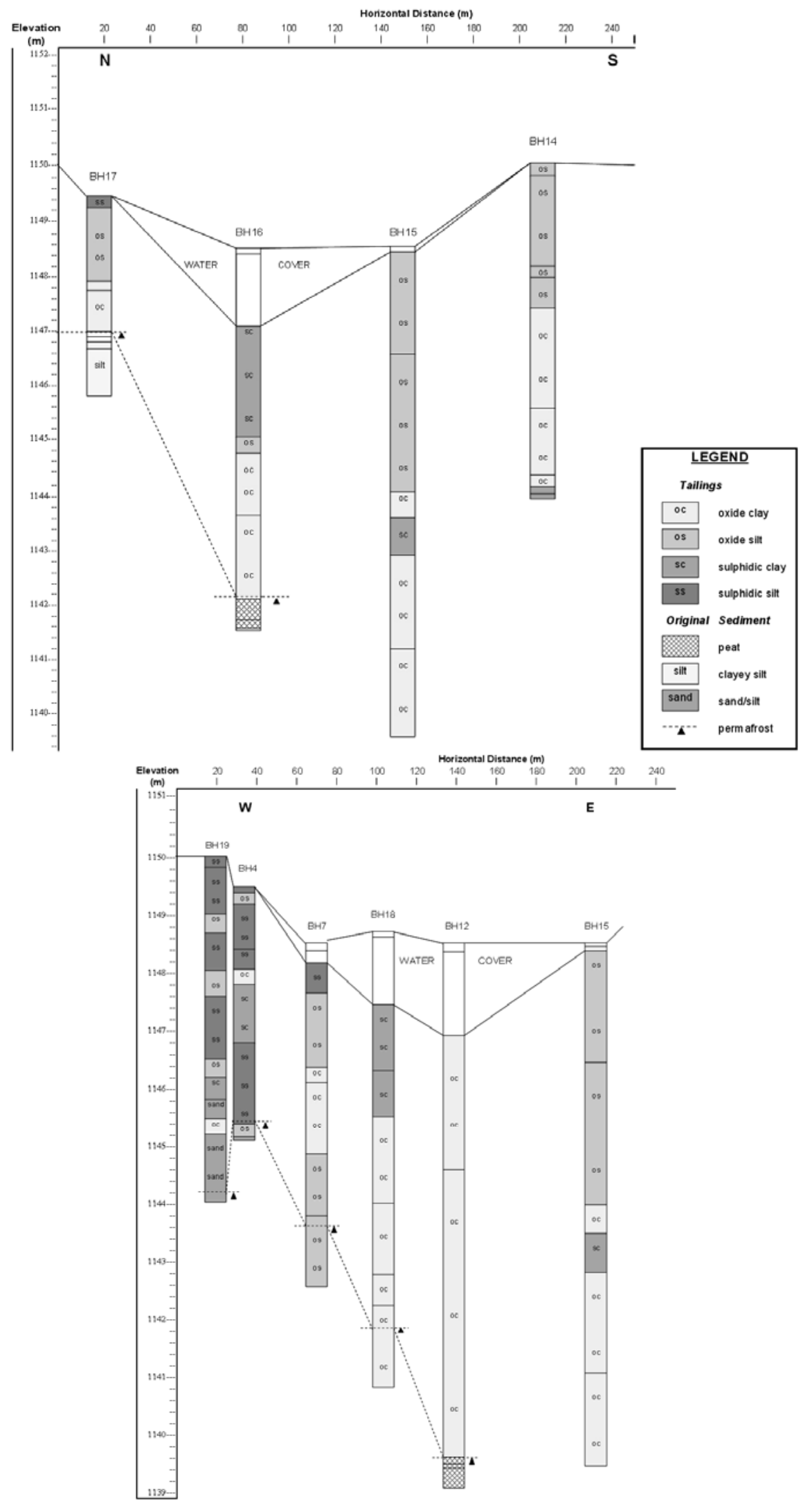

Figure 2 Selected N-S (left) and W-E (right) cross sections of the Mount Nansen tailings impoundment, showing the distribution of various tailings types and the location of the permafrost table 

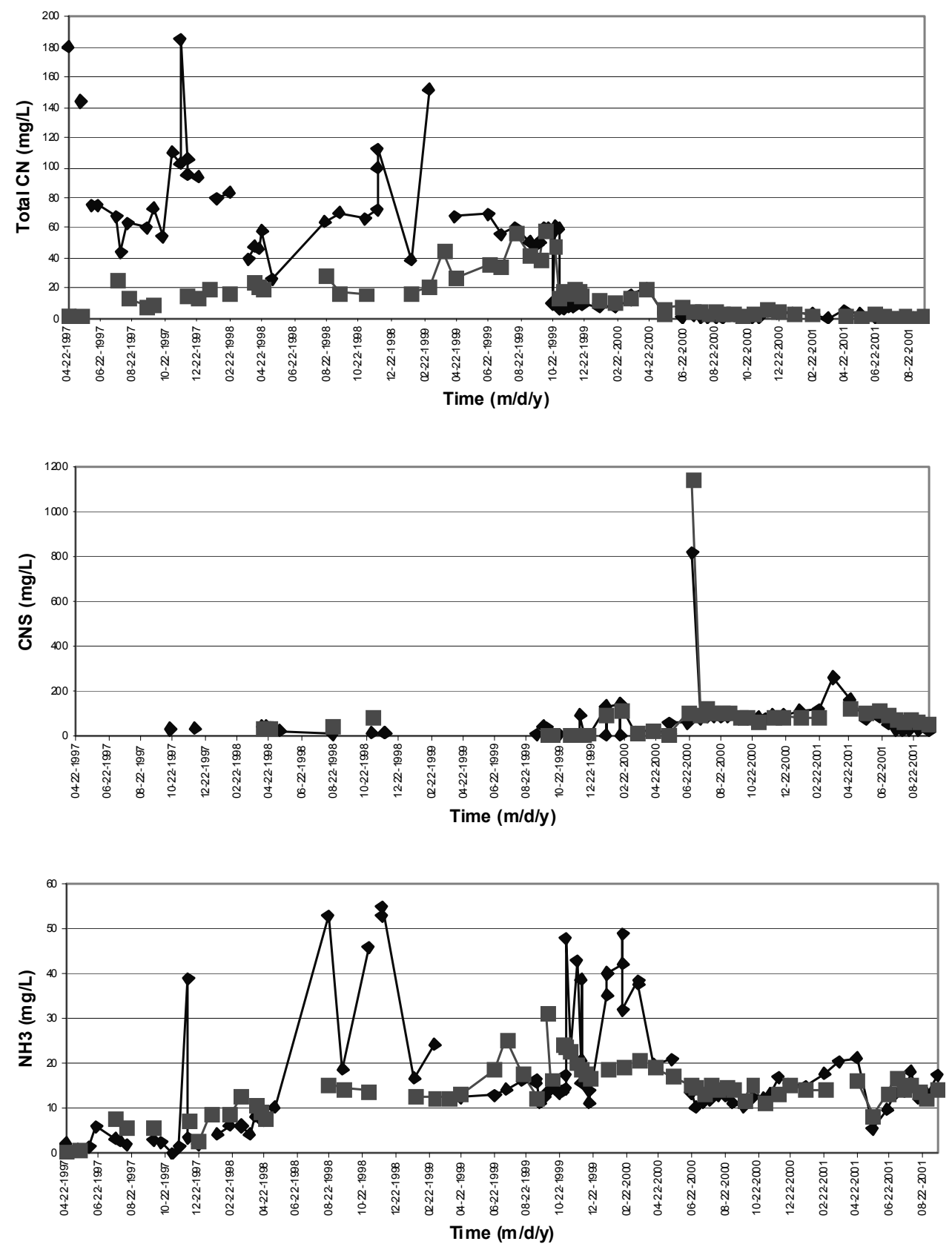

Figure 3 Temporal variation of total $\mathrm{CN}$ (top), $\mathrm{CNS}$ (middle) and $\mathrm{NH}_{3}$ (bottom) in the tailings pond water (diamonds) and seepage return (squares) at the Mount Nansen Mine site from April 1997 to September 2001

At closer examination, the temporal variation of total $\mathrm{Cu}$ in the seepage return water (Figure 4, middle plot) also correlates with that of total $\mathrm{CN}$ in the seepage return (Figure 3, top plot). This suggests the formation of copper cyanide complex in the tailings pore water during mining operation. The total $\mathrm{CN}$ and total $\mathrm{Cu}$ concentrations in both the tailings pond water and seepage return have been greatly reduced since mine abandonment. 

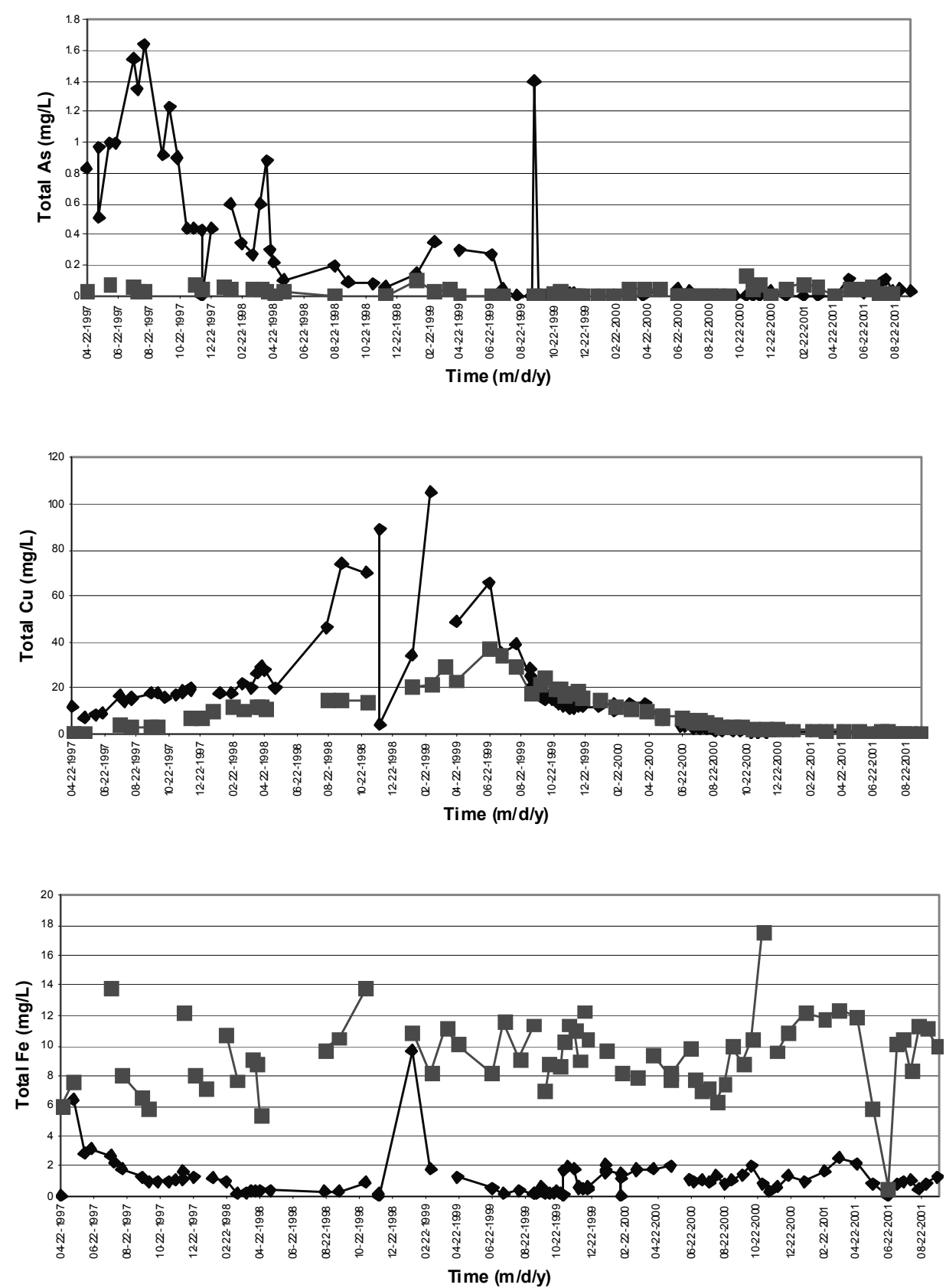

Figure 4 Temporal variation of total As (top), total $\mathrm{Cu}$ (middle) and total $\mathrm{Fe}$ (bottom) in the tailings pond water (diamonds) and seepage return (squares) at the Mount Nansen site from April 1997 to September 2001

\subsection{Tailings composition and leach testing}

Generally, the tailings are heterogeneous in composition with anomalous contents of $\mathrm{As}, \mathrm{Cu}, \mathrm{Pb}, \mathrm{Sb}$ and $\mathrm{Zn}$ in addition to elevated cyanide and related compounds. The average concentrations of these elements and compounds in the tailings solids and pore water are shown in Table 1 according to tailings type. The Ag content varies between 10 and $80 \mu \mathrm{g} / \mathrm{g}$ but $\mathrm{Au}$ is generally below the analytical detection limit of $4 \mu \mathrm{g} / \mathrm{g}$. The total cyanide content varies from 5 to $165 \mu \mathrm{g} / \mathrm{g}$ with most high values associated with the fine tails. With a relatively low sulphide-S content (less than $4 \mathrm{wt} \%$ ) and a maximum net neutralisation potential (NNP) of only $-52 \mathrm{~kg} \mathrm{CaCO} /$ tonne, acid rock drainage is unlikely a serious long-term issue with the impounded tailings. This is because an examination of the tailings under a scanning electron microscope has shown that a greater proportion of the sulphides are encapsulated in quartz particles, rendering the maximum effective NNP to about $-20 \mathrm{~kg} \mathrm{CaCO}_{3} /$ tonne, a value generally considered inconsequential. 
Table 1 Average concentration of selected elements and cyanide-related compounds in the four tailings types at Mount Nansen

\begin{tabular}{lllll}
\hline Parameters & Oxide Silt & Sulphidic Silt & Oxide Clay & Sulphidic Clay \\
\hline Tailings Solids & & & & \\
$\mathrm{As}(\mu \mathrm{g} / \mathrm{g})$ & 2,800 & 2,270 & 4,930 & 3,590 \\
$\mathrm{Cu}(\mu \mathrm{g} / \mathrm{g})$ & 290 & 365 & 483 & 356 \\
$\mathrm{Fe}(\%)$ & 4.85 & 5.02 & 6.66 & 6.06 \\
$\mathrm{~Pb}(\mu \mathrm{g} / \mathrm{g})$ & 1,470 & 1,800 & 4,510 & 2,750 \\
$\mathrm{Sb}(\mu \mathrm{g} / \mathrm{g})$ & 386 & 433 & 847 & 443 \\
$\mathrm{Zn}(\mu \mathrm{g} / \mathrm{g})$ & 1,020 & 1,940 & 1,590 & 1,920 \\
Total CN $(\mu \mathrm{g} / \mathrm{g})$ & 41.8 & 32.6 & 29.2 & 72.7 \\
Total S $(\%)$ & 2.30 & 2.36 & 1.38 & 1.96 \\
\hline Tailings Pore Water & & & & \\
$\mathrm{As}(\mathrm{mg} / \mathrm{L})$ & 1.12 & 0.421 & 2.33 & 0.494 \\
$\mathrm{Cu}(\mathrm{mg} / \mathrm{L})$ & 6.5 & 5.1 & 6.4 & 3.6 \\
$\mathrm{Fe}(\mathrm{mg} / \mathrm{L})$ & 3.4 & 0.30 & 1.8 & 0.48 \\
$\mathrm{Zn}(\mathrm{mg} / \mathrm{L})$ & 0.055 & 0.488 & 0.096 & 0.078 \\
Total CN $(\mathrm{mg} / \mathrm{L})$ & 16.6 & 3.9 & 9.9 & 4.3 \\
$\mathrm{CNO}(\mathrm{mg} / \mathrm{L})$ & 41.7 & 58.0 & 50.7 & 25.0 \\
$\mathrm{CNS}(\mathrm{mg} / \mathrm{L})$ & 140 & 104 & 118 & 168 \\
Ammonia $(\mathrm{mg} / \mathrm{L})$ & 30.2 & 32.2 & 19.6 & 34.0 \\
\hline
\end{tabular}

The leachability of potentially deleterious elements and process chemicals as well as their degradation products in the tailings has been investigated by column testing simulating different disposal scenarios for the tailings (Kwong et al., 2003). Of particular relevance here is a flow-through experiment simulating the leaching of exposed tailings by natural precipitation. The experiment was conducted in duplicate using plexiglass columns of $15.2 \mathrm{~cm}$ in inner diameter and $1 \mathrm{~m}$ in height. Each column was filled with $6.2 \mathrm{~kg}$ of mixed oxide and sulphidic silty tailings, through which $190 \mathrm{~mL}$ of relatively uncontaminated meteoric water from the Mount Nansen site was passed twice a week at a rate of $6 \mathrm{~mL} / \mathrm{min}$. The water application was five times the average annual precipitation at the site but was required to render sufficient amounts of leachate for various analyses. Through three months of experimentation, only CNS, ammonia (NH4-N), sulphate, As and Sb showed any significant leaching at some stage of the testing (Figure 5). While the CNS concentration dropped to non-detectable level within a month, the release of ammonia decreased more slowly to render it a concern at least for the medium term. The leaching of sulphate averaging close to $2,000 \mathrm{mg} / \mathrm{L}$ throughout the experiment appears to be influenced by the dissolution of gypsum contained in the tailings solids. The As concentration increased initially but later stabilised to slightly below $1 \mathrm{mg} / \mathrm{L}$ after seven weeks of testing. The leaching of $\mathrm{Cu}, \mathrm{Zn}$ (which are not plotted) and $\mathrm{Sb}$ were significantly attenuated within the first three weeks of testing with the average leachate concentrations stabilised at $<0.03,0.03$ and $0.08 \mathrm{mg} / \mathrm{L}$, respectively. The release of total $\mathrm{CN}$ was insignificant throughout the leaching experiment.

Due to their fine grain-size and inherent low permeability, the clayey tailings could not be tested for their leaching behaviour with column experiments. Instead, a sequential batch test was conducted separately on the oxide and sulphidic clayey tailings following the procedure described by Filipek (1999). The batch test was designed to study the impact of varying water to solid ratios on the extent of leaching and help to reveal the dominant leaching mechanisms. The test results showed that only arsenic, antimony and sulphate were significantly leached from the fine tailings (Kwong et al., 2003). The release of sulphate was again controlled by the solution of gypsum in both the oxide and sulphidic tailings. The release of As and Sb from the two types of fine tailings appeared to be dominated by different mechanisms. For the sulphidic clayey tailings, the leaching of $\mathrm{As}$ and $\mathrm{Sb}$ was apparently controlled by slow desorption and dissolution reactions. In 
contrast, rapid ionic exchange probably dominated the release of As and $\mathrm{Sb}$ from the oxide tailings, especially under high dilution conditions (Kwong et al., 2003).
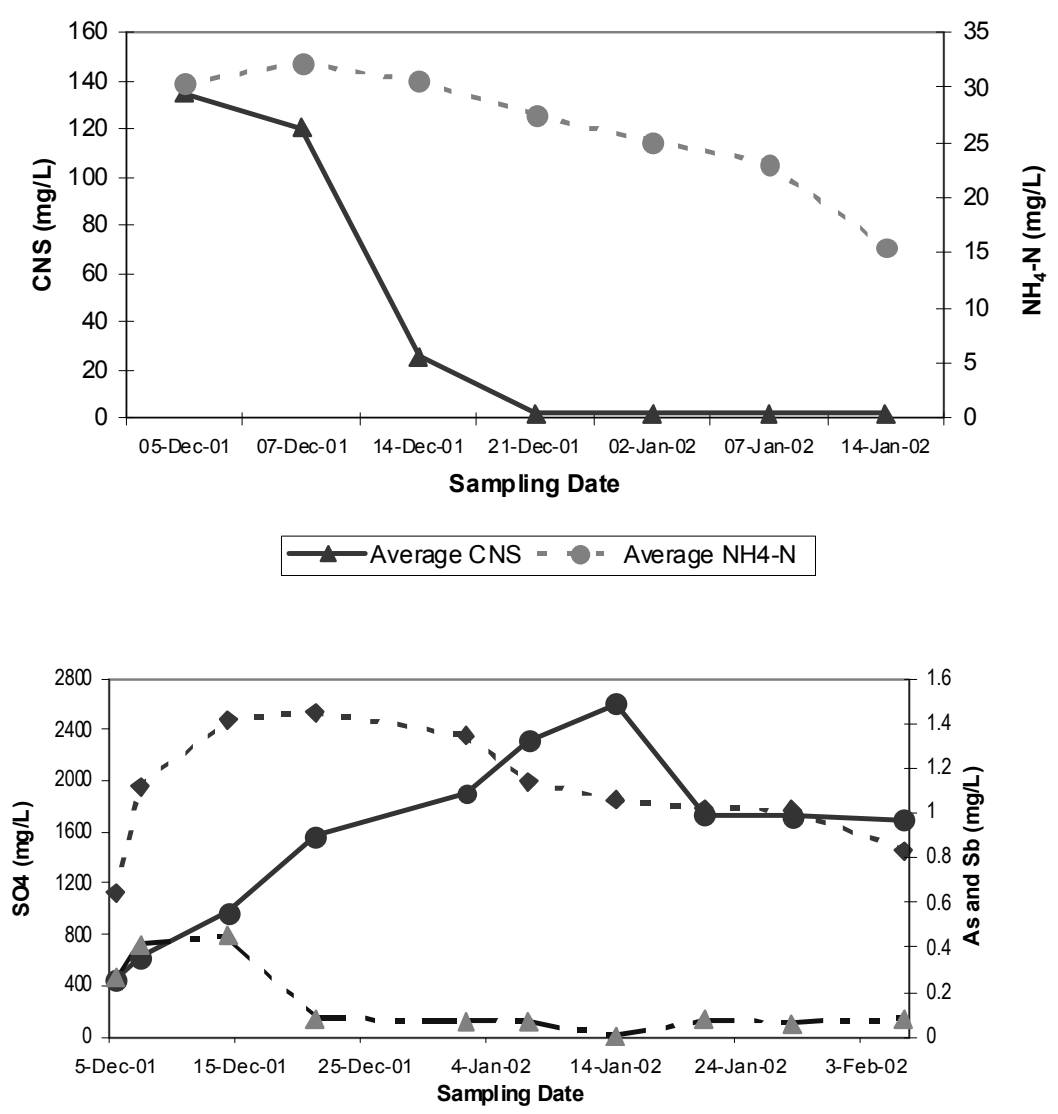

$-\diamond$ - Average SO4 $\longrightarrow$ Average As $\longrightarrow-$ Average Sb

Figure 5 Time series of the average concentration of thiocyanate, ammonia, sulphate, arsenic and antimony in the weekly leaches of the flow-through column experiment

In addition to the column and batch leach testing, the partitioning of trace elements in the more labile fractions of the tailings was determined using the sequential extraction procedure of Hall et al. (1996). The main findings of the analysis are as follows (Kwong et al., 2003):

- Amorphous $\mathrm{Fe} \pm \mathrm{Mn}$ oxyhydroxides are a significant host for $\mathrm{Cu}, \mathrm{Pb}, \mathrm{Zn}$ and $\mathrm{As}$ in the Mount Nansen tailings.

- With close to $40 \%$ of the total concentration occurring as adsorbed and exchangeable ions as well as in carbonate form or associated with amorphous Fe/Mn oxides, $\mathrm{Zn}$ is very susceptible to leaching with changing environmental conditions.

- Presumably due to their larger specific surface area, the clayey tailings apparently host more adsorbed and exchangeable As than their silty counterparts. In general, sorption with clay minerals also appears to be an important mechanism for attenuating aqueous transport of As at Mount Nansen.

- With less than $5 \%$ of the total concentration occurring in readily releasable forms, most $\mathrm{Sb}$ is likely locked up in sulphosalts in the tailings.

Total CN was also analysed at each step of the sequential extraction. However, all the analyses were below the analytical detection limit of $0.05 \mathrm{mg} / \mathrm{L}$. It thus appears that total $\mathrm{CN}$ is not readily leached but attenuates through natural degradation reactions. 


\section{Discussion - options for long-term reclamation of the impounded tailings}

In a thorough review of the economic potential of the Mount Nansen property and the main outstanding environmental and reclamation issues shortly after mine abandonment, Strathcona Mineral Services Limited (2000) suggested three options for reclaiming the impounded tailings. These are:

1. Redistribute tailings within the existing impoundment and construct a low permeability cover over the tailings such that no water is impounded behind the dam.

2. Relocate some tailings to the Brown-McDade open pit and submerge them behind a new pit dam while the existing tailings dam is maintained to flood the remaining tailings under reduced hydraulic stress.

3. Relocate all of the tailings to the Brown-McDade pit to be flooded behind a new pit dam and the existing tailings dam of questionable physical integrity is removed.

The selection of an optimum option was to be informed by details on the chemical stability of the impounded tailings as well as the hydrology and hydrogeology of the Brown-McDade open pit, which were not known at the time. Since then, the study of Kwong et al. (2003) has clarified the short and long-term chemical stability of the impounded tailings and the investigation of Gartner Lee Limited (2004) and subsequent ongoing work have shed much light on the hydrological and hydrogeological settings of the open pit. As similar strategies are being pondered today to develop a permanent decommissioning plan for the site, it is worthwhile to review the pros and cons of the suggested options and explore other alternatives in the view of new information acquired to date.

From the tailings characterisation and field water quality monitoring data as well as laboratory testing results presented above, it is apparent that the impounded tailings form a relatively stable chemical system despite their elevated levels of potentially deleterious elements such as $\mathrm{As}, \mathrm{Cu}, \mathrm{Pb}, \mathrm{Sb}$ and $\mathrm{Zn}$ and $\mathrm{CN}$-related compounds. Although the tailings pore water contains unacceptable concentrations of many of the named trace elements, the latter appear to have reached a steady state and not escaped the impoundment to date. While the CNS and ammonia levels in the tailings pore water and pond water may continue to remain a concern in the medium term, continual natural degradation of the $\mathrm{CN}$ and derived compounds will mitigate their long-term risk and impact. Thus it seems logical to retain the tailings in the existing impoundment if the physical integrity of the containment dam is assured.

As is evident from the brief description of the current status of the tailings impoundment above, the two primary causes of dam instability are (1) a thawing foundation; and, (2) a high hydraulic head on the upstream side as the designed $50 \mathrm{~m}$ of tailings beach along the upstream face of the dam is still not achieved during most of the year. The return of collected seepage back to the impoundment for storage prior to treatment and discharge further accentuates the latter problem. Thus replacing the water cover with a low permeability cover as suggested in the first option above may be practical except that care must be taken to prevent the development of reducing conditions beneath the new cover. It is well known that arsenic is more mobile under reducing conditions and the reductive dissolution of iron and manganese oxyhydroxides accumulated in the tailings impoundment may release the sorbed trace elements. Given that frozen ground still underlies most of the impoundment and the containment dam still has a satisfactory safety factor against slope failure, a better alternative may be to dewater the pond, redistribute the tailings and cover them with a layer of benign waste rock, which abounds at the mine site. If deemed necessary, the dam height can also be reduced and the downstream face of the earth dam further reinforced with a new rock berm. Such a scheme will maintain an oxidising environment for the impounded tailings, ensuring their chemical stability, reduce erosion, prevent direct access of roaming animals to the tailings and safeguard the physical integrity of the dam even though some of the foundation soils may still thaw with climatic warming. The major concern with thawed foundations is the increased potential for liquefaction of the embankment and foundation soils, especially under seismic stress. Converting the existing impoundment to a dry facility in conjunction with downstream berm reinforcement will greatly reduce the risk.

Both the second and third reclamation options suggested by Strathcona Mineral Services Limited (2000) involve moving the tailings to the Brown-McDade pit and the construction of a new tailings dam at the open pit. Not only will such a scheme be likely more expensive than retaining the tailings in the existing impoundment, it will also risk releasing the highly contaminated tailings pore water to the surface 
environment and a temporary increase in generation of thiocyanate and ammonia due to the exposure and oxidation of cyanide and related compounds contained in the tailings during the transfer and prior to eventual settling in the new pit impoundment. The advantage, on the other hand, is a more rapid depletion of the stock of CN-related compounds and a reduction in acid generation in portions of the pit floor and pit wall that are known to contain sulphide mineralisation (Conor Pacific Environmental Technologies Inc., 2000). However, care must also be taken to prevent the development of reducing conditions in the new pit lake, which, as suggested by the laboratory leach tests and sequential extraction analyses, may lead to trace element remobilisation from the tailings. Given the relative low acid generating capacity of the impounded tailings, a water cover is not really essential for their permanent decommissioning. From the perspective of taking advantage of what nature has to offer at the Mount Nansen site, it appears that the two proposed options of relocating tailings to the Brown-McDade open pit are less attractive than a modified scheme of retaining the tailings in the existing impoundment.

\section{Conclusion}

Based on a review of available information on the geological and environmental settings of the Mount Nansen site, the current physical status of the impoundment structure, the geochemical characteristics and chemical stability of the impounded tailings as well as archived water monitoring data, the following conclusions with regard to permanent reclamation of the impounded tailings can readily be drawn:

1. Retaining the tailings in the existing impoundment is preferred to relocating them to the BrownMcDade pit to prevent potential trace element remobilisation.

2. As a water cover is not essential to assure the chemical stability of the impounded tailings, the tailings pond can be dewatered and the tailings redistributed and covered with a layer of benign waste rock to arrest erosion and prevent direct access of the odd occasional visitors to the tailings.

3. The long-term physical integrity of the existing dam can be further enhanced by reducing the dam height and additional downstream reinforcement with a rock berm.

The implementation of all the above measures will probably represent the most cost-effective and practical strategy for permanently decommissioning the impounded tailings at the abandoned mine site.

\section{Acknowledgements}

The author is grateful to Janice Zinck for internal review of this paper prior to its submission and to his colleagues at the CANMET Mining and Mineral Sciences Laboratories for their support and assistance in completing the various studies described in the paper. Opinions expressed herein are entirely the author's own. They do not represent the position of Natural Resources Canada or any other Federal and Territorial agencies with whom the author has communicated in the course of conducting his research.

\section{References}

AGRA Simons Ltd. (2000) Memorandum: Reclaim Water Treatment System Upgrade, Mount Nansen Mine, prepared for Indian and Northern Affairs Canada, February 18, 2000.

Carlson, G.C. (1987) Bedrock geology of the Mount Nansen and Stoddart Creek map areas (115I/03 and 115I/06), Exploration and Geological Services Division, Yukon, Indian and Northern Affairs Canada, Open File 1987-2.

Conor Pacific Environmental Technologies Inc. (2000) Mt. Nansen Minesite Historical Review, Site Assessment and Field Sampling Program, prepared for Indian and Northern Affairs Canada, February 2000.

EBA Engineering Consultant Ltd. (1999) Geotechnical Data Review Report, Mount Nansen Tailings Dam Safety Evaluation, prepared for Indian and Northern Affairs Canada, December 1999.

Filipek, L.H. (1999) Determination of the source and pathway of cyanide-bearing mine water seepage, in The Environmental Geochemistry of Mineral deposits, Part B: Case Studies and Research Topics, L.H. Filipek and G.S. Plumlee (eds), reviews in Economic Geology, Vol. 6B, pp. 549-565.

Gartner Lee Limited (2004) Mt. Nansen Mine Site - Brown McDade Pit Hydrological and Hydrogeological Investigation, prepared in association with Northwest Hydraulic Consultants Ltd. and Lorax Environmental Services Ltd. for Yukon Energy, Mines and Resources, Abandoned Mines Project Office, June 2004.

Government of Canada (2005) Taking action on federal contaminated sites: An environmental and economic priority, Environment Canada, Gatineau, July 2005, 20 p. 
Hall, G.E.M., Gauthier, G., Pelchat, J-C., Pelchat, P. and Vaive, J.E. (1996) Application of a sequential extraction scheme to ten geological certified reference materials for the determination of 20 elements, Journal of Analytical Atomic Spectrometry, Vol. 11, pp. 787-796.

Hart, C.J.R. and Langdon, M. (1997) Geology and mineral deposits of the Mount Nansen camp, Yukon, Yukon Exploration and Geology 1997, Exploration and Geological Services Division, Yukon, Indian and Northern Affairs Canada, pp. 129-138.

Klohn Crippen Consultants Ltd. (1995) Tailings Impoundment - Final Design Report, prepared for BYG Resources Inc., August 1995.

Klohn Crippen Consultants Ltd. (2000) BYG Tailings Dam, Mount Nansen, YT, Project Data Review Report, prepared for Indian and Northern Affairs Canada, January 2000.

Kwong, Y.T.J., Kapoor, A., Fiset, J-F. and McAlpine, B. (2003) Assessment of chemical stability of the impounded tailings at Mount Nansen, Yukon Territory, in Proceedings 7th International Symposium on Mining in the Arctic, J.E. Udd and G. Bekkers (eds), March 30 - April 1, Iqaluit, Canada, Canadian Institute of Mining, Metallurgy and Petroleum, Montreal, pp. 355-367.

Strathcona Mineral Services Limited (2000) A Review of the Mt. Nansen Property, Yukon Territory, prepared for Department of Indian Affairs and Northern Development, December 2000. 
